\title{
Adaptation of Cowpea (Vigna unguiculata (L.) Walp.) to Water Deficit during Vegetative and Reproductive Phases Using Physiological and Agronomic Characters
}

\author{
Vincent Ezin $\mathbb{D}^{1},{ }^{1}$ Artoche Gloria Christelle Tosse, ${ }^{1}$ Ifagbémi Bienvenue Chabi ${ }^{\mathbb{D}},{ }^{2}$ \\ and Adam Ahanchede $\mathbb{D}^{1}$ \\ ${ }^{1}$ Department of Crop Production, Faculty of Agricultural Sciences, University of Abomey-Calavi, 01 BP 526 Cotonou, Benin \\ ${ }^{2}$ Laboratory of Valorization and Quality Management of Food Bio-Ingredients, Faculty of Agricultural Sciences, \\ University of Abomey-Calavi, 01 BP 526 Cotonou, Benin
}

Correspondence should be addressed to Vincent Ezin; ishola.vincent@yahoo.com

Received 29 June 2021; Revised 6 October 2021; Accepted 28 October 2021; Published 16 November 2021

Academic Editor: Mathias N. Andersen

Copyright ( 2021 Vincent Ezin et al. This is an open access article distributed under the Creative Commons Attribution License, which permits unrestricted use, distribution, and reproduction in any medium, provided the original work is properly cited.

Cowpea (Vigna unguiculata (L.) Walp.) is an important commodity in West Africa. Its seeds are a valuable source of protein, vitamins, and income for humans. However, cowpea cultivation in Benin faces climatic constraints such as water stress caused by a prolonged absence of rain during the rainy season. Thus, this work aims at selecting cowpea varieties that can be cultivated in times of drought without compromising their yields and yield components. Twenty cowpea varieties were used, including 17 improved cultivars and 3 landraces. The experiment was conducted at the International Institute of Tropical Agriculture in Benin and laid at a split-plot design with four replicates. Each genotype was exposed to three water treatments: fully irrigated control, vegetative stress (when plants were 23 days old, drought stress was imposed for 30 days), and reproductive stress (once the first flowers were observed, water stress was imposed for 30 days). The results showed that photochemical yield, chlorophyll content, and relative water content were reduced under water deficit at the vegetative and reproductive stages. But there were no significant differences in proline content among cowpea varieties. Agronomic traits such as number of days to flowering, number of pods, yield per plant, the weight of 100 seeds, and harvest time showed significant differences under water stress. Overall, the landraces and cultivars including Kpodjiguegue, KVX 61-1, and IT 06-K-242-3 were the most tolerant to drought stress at the vegetative and reproductive stages and could potentially be used in breeding programs to improve drought tolerance of cowpeas.

\section{Introduction}

Cowpea (Vigna unguiculata (L.) Walp.) is one of the oldest crops known to man. It is native to Africa, and it was domesticated from a wild plant to a cultivated plant [1]. It is widely adapted and cultivated around the world on about 14.5 million hectares, and approximately 6.5 million metric tons of cowpea is yearly harvested [2]. Of the total area of around 14.5 million hectares planted with cowpeas worldwide, West Africa alone accounted for around 10.6 million hectares in 2017 [3]. Many cowpea producers in Africa are smallholder farmers. Many Africans consume cowpea as fresh pods, tender leaves, and grains $[4,5]$. It is the most economically important indigenous African pulse crop [6] and is of vital importance to the livelihoods of millions of people in West and Central Africa. In Benin, cowpea is cultivated nationwide mainly for its edible seeds [7], and it occupies $7 \%$ of the areas sown for annual crops with a production of 11,224 tonnes [8,9].

One of the key characteristics of cowpea is that it can withstand dry environmental conditions, making it the crop of choice in semiarid/arid areas of West and Central Africa. Additionally, when grown together, cowpea is the first crop harvested before cereals get ready and is therefore referred to as a "hungry season crop" [10]. Owing to its capacity for symbiotic fixation of atmospheric nitrogen, the inclusion of 
cowpea in crop rotations makes it possible to meet the nitrogen fertilizer needs of subsequent crops which help increase their yields and subsequently contributes to the sustainability of cropping systems [11-13].

Due to its high protein (19-25\%), carbohydrate, and mineral content, cowpea plays an important role in human nutrition and the fight against malnutrition [14]. With over $25 \%$ protein in the seeds as well as in the young leaves (in dry weight), cowpea is a major source of protein, minerals, and vitamins in the daily human diet and is just as important as nutritious fodder for livestock $[15,16]$. Cowpea is Africa's most versatile crop; it feeds people and their livestock.

Water deficit is a key limiting factor to cowpea production due to poor and irregular rainfall [17]. However, cowpea exhibits, to some extent, resistance to water stress when compared to other crops [17-19]. Cowpea demonstrates tolerance to water stress conditions that could have been very disastrous to several other annual crops. It is also able to produce a higher yield under dry conditions than any other cultivated crop. When resuming watering after a drought spell, the yield of cowpea is similar to that of a normally irrigated control [20]. However, cowpea is heavily damaged by repeated water deficits in the savannah and Sahel [21]. Early maturing cowpea genotypes are susceptible to water deficit during flowering and fruit setting phases [22]. Cowpeas yield more than $1000 \mathrm{~kg}$ of grains/ha, but drought reduces this potential to around $360 \mathrm{~kg} / \mathrm{ha}$ especially when stress sets in during preflowering [23, 24]. Similarly, in some drier locations in Niger, the average yield is about 20 times lower than the average yield in the United States where water is plentiful [25]. IPCC [26] has shown that predicted climate changes will further exacerbate extreme events. Cowpea resistance to water stress lies in its ability to maintain leaf turgor [27]. Despite its capability to resist water deficit more than any other legume grown in the tropics [28, 29], a significant difference exists between cowpea varieties adapted to water deficit conditions [30, 31]. "Morphophysiological characteristics can be used to select for drought-tolerant genotypes." Therefore, the objectives of this study were to (1) study the effect of water stress at the vegetative and reproductive stages of twenty cowpea varieties, (2) identify the physiological and agronomic traits that explain drought tolerance in cowpea, and (3) identify highyielding performing genotypes that can withstand drought conditions.

\section{Materials and Methods}

2.1. Plant Material and Growth Conditions. The experiment was conducted at the International Institute of Tropical Agriculture (IITA) in Benin, Africa. Twenty cowpea genotypes, including three local landraces and seventeen hybrids, were screened for their tolerance to drought. The landraces collected originally in Benin were Gboto (V7), Kpodjiguegue (V19), and Tawa (V20), and the improved varieties tested are commonly grown in Benin, as well as Burkina-Faso, and included IT 97K-556-6 (variety $1=\mathrm{V} 1$ ), KVX 61-1 (V2), KVX 396-18 (V3), IT 87 S-1390 (V4), IT 99K-573-2-1 (V5), IT 86 D-888 (V6), IT 84 S-2246-4 (V8), IT 07K-206-1-1
(V9), IT 99K-573-1-1 (V10), IT 84 D-449 (V11), IT 84 E-124 (V12), IT 93K-452-1 (V13), IT 86 D-1038 (V14), IT 07K188-49 (V15), IT 06K-242-3 (V16), IT 07 K-211-1-8 (V17), and IT 86 D-1033 (V18). Each experimental pot was filled with $20 \mathrm{~kg}$ of soil with $500 \mathrm{~g}$ of poultry manure. Five percent diluted carbofuran was used to treat the soil against microorganisms. The seeds were sown on November 18, 2019. The seeds were watered daily. Plants were grown under natural conditions. During the experiment, weather data were collected and plotted (Figure 1). The pots were handweeded regularly and were sprayed weekly with abamectin $(18 \mathrm{~g} / \mathrm{L})$ and cyhalothrin $(25 \mathrm{~g} / \mathrm{L})$ to protect the plants from the attack of insect pests and plant pathogens. The drought stress at the vegetative stage was imposed on December 10, 2019, and ended on January 08, 2020, while the drought stress at the reproductive stage started on December 23, 2019 , and it was terminated on January 21, 2020. There was no rainfall during the drought imposition at both vegetative and reproductive stages.

2.2. Drought Treatments and Experimental Design. A split plot with 4 replications and 2 factors was used. The main factor was water regime with 3 levels: $\mathrm{RO}=$ no drought, $R 1=$ vegetative stress, and $R 2=$ reproductive stress. That is, two drought treatments were initiated, one at the vegetative stage and one at the reproductive stage. For the vegetative stage, drought treatments were initiated 23 days after sowing during. Plants were either irrigated daily or exposed to drought (no water) for 30 days. For the reproductive stage, the drought stress was initiated 40 days after sowing, when the first flowers appeared. During this reproductive phase, plants were either watered daily or exposed to drought for 30 days. The subplot was the variety factor with 20 levels (V1 to $\mathrm{V} 20$ ). This generated 60 interactions repeated 4 times given 240 experimental units (Pots). The pots were spaced $0.6 \mathrm{~m}$ apart within the rows and $0.4 \mathrm{~m}$ apart between the rows. Replications were separated from each other by $2 \mathrm{~m}$.

2.3. Measurements. A portable chlorophyll meter (Minolta SPAD-502, Soil Plant Analysis Development, Minolta Co., Osaka, Japan) was used to determine the chlorophyll content of the cowpea plants. Chlorophyll fluorescence was also measured with a portable chlorophyll fluorometer (Model OS-30P; Opti-Sciences, New Hampshire, USA). Data on fluorescence were collected from fully expanded leaflets clipped from the upper part of the plant canopy, after a 1hour dark adaptation period. Dark fluorescence $\left(F_{o}\right)$, maximal fluorescence $\left(F_{m}\right)$, and photochemical yield $\left(F_{v} / F_{m}\right.$, where $F_{v}=F_{m}-F_{o}$ ) were recorded. After stress, the relative water content (RWC) of different plants was determined. Here, 3 leaflets on the third leaf from the apex were taken per plant in each treatment and immediately wrapped in aluminum foil to avoid loss of water. The samples were brought to the laboratory to determine their fresh weight (FW). The leaflets were placed in bottles containing $150 \mathrm{ml}$ of distilled water left in the dark for 24 hours at $16^{\circ} \mathrm{C}$ [32]. The leaf discs were then removed and weighed again to determine the weight of the full turgor (WFC). The dry weight (DW) was 


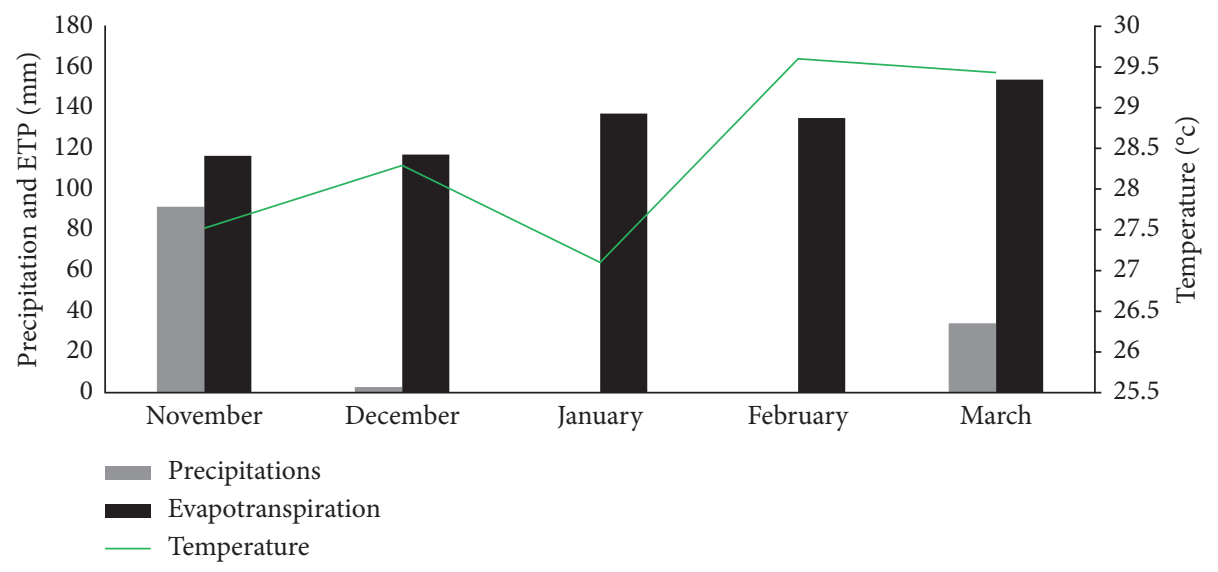

Figure 1: Climate data in the station.

obtained after oven-drying at $80^{\circ} \mathrm{C}$ for 24 hours. The weighing of the leaf discs was carried out using a $0.01 \mathrm{~g}$ precision balance. The relative water content (RWC) of the leaves was calculated by the formula of Turner and Begg [33]: $\mathrm{RWC}=(\mathrm{FW}-\mathrm{DW}) /(\mathrm{WFC}-\mathrm{DW}) \times 100$. Proline was determined according to Bates and Hall [34]. Under drought stress at the reproductive stage, fresh tissue $(0.25 \mathrm{~g})$ was collected and homogenized in $10 \mathrm{ml}$ of water with $3 \%$ of aqueous sulfosalicylic acid. After 3 hours, the mixture was centrifuged at $1500 \mathrm{~g}$ for $10 \mathrm{~min}$. After removing $2 \mathrm{ml}$ of the supernatant, $2 \mathrm{ml}$ of glacial acetic acid and $2 \mathrm{ml}$ of hydrofluoric acid were added to the supernatant and boiled at $100^{\circ} \mathrm{C}$ in a water bath for one hour. The reaction was stopped by placing it on ice. $4 \mathrm{ml}$ of toluene was added and mixed vigorously using the vortex for 15-20 seconds, and the toluene containing the chromophore was separated using a separatory funnel and the absorbance was measured at $520 \mathrm{~nm}$ in a spectrophotometer against an appropriate toluene blank. The proline content was determined from a standard curve prepared with L-proline and expressed in $\mathrm{mg} / \mathrm{g}$ MS. The unknown proline content is calculated from the samples using the standard graph. The proline concentration is then calculated with

$$
\frac{e \times \mathrm{V} 1 \times \mathrm{V} 2}{\mathrm{gFr} . \mathrm{MF} \times 115,5},
$$

where $e$ is the $\mu \mathrm{g} / \mathrm{ml}$ proline, $\mathrm{V} 1$ is the toluene volume, $\mathrm{V} 2$ is the volume of sulfosalicylic acid, and $g$ Fr.MF is the $g$ of the dry sample.

Agronomic traits measured included the number of days from sowing to flowering, number of pods per plant, yield per plant, the weight of 100 grains, and harvest time, i.e., from the first harvest to the last.

2.4. Statistical Analysis. Data were analyzed statistically using analysis of variance (ANOVA). Principal component analysis (PCA) was also carried out based on all measured parameters (physiological and agronomic traits measured) to identify the main characteristics contributing to the variability observed between the varieties. Based on these groups, an analysis was carried out to identify water stress yet high-yielding genotypes. All analyses were performed with $\mathrm{R}$ version 4.0 software. The separation of the means for the various measured parameters was carried out by the Student Newman Keuls test.

\section{Results}

3.1. Physiological Traits. Water stress significantly $(p<0.001)$ reduced the $F_{v} / F_{m}$, RWC, and chlorophyll content of genotypes. However, KVX 61-1 (V2), Kpodjiguegue (V19), and GBOTO (V7) recorded the highest values for $F_{v} / F_{m}(0.90825 ; 0.88225$, and 0.80675 , respectively) and RWC (85.3700, 90.8750, and 90.1350, respectively) among stressed plants at the end of vegetative stress (Table 1). At the end of reproductive stress, there was a significant $(p<0.001)$ difference between genotypes for physiological parameters such as photosynthetic yield, chlorophyll content, and relative water content. Chlorophyll fluorescence decreased in stressed plants during the vegetative phase. Nevertheless, KVX 61-1 and Kpodjiguegue were not affected by the stress because their photosynthetic yield values obtained were optimal (0.800). At the end of the reproductive phase, we observed the same result for KVX 61-1 and Kpodjiguegue. But KVX 61-1 (V2), Gboto (V7), and Kpodjiguegue (V19) recorded the highest average mean values of $F_{v} / F_{m}$, thus indicating the genotypes with the best performance under drought stress during the reproductive stage. Chlorophyll content increased in almost all the stressed plants at the vegetative phase; especially in KVX 61-1 (V2), IT 84E-124 (V12), IT 93K-452-1 (V13), IT 86 D-1038 (V14), Kpodjiguegue (V19), and Gboto (V7) whereas, at the reproductive stage, their chlorophyll contents were negatively affected by drought conditions when compared with the controls, indicating that reproductive stage was the most affected. Relative water content was significantly $(p<0.01)$ decreased in stressed plants during the vegetative and reproductive phases. KVX 61-1, Gboto, and Kpodjiguegue recorded the highest relative water content during the vegetative phase, while KVX 61-1 (V2), IT 84 S-2246-4 (V8), IT 84 D-449 (V11), IT 07K-188-49 (V15), IT 06K-242-3 (V16), and Kpodjiguegue (V19) performed better than others in the reproductive stage. The proline content in plants under 
TABLE 1: Average physiological parameters under drought stress at vegetative phase.

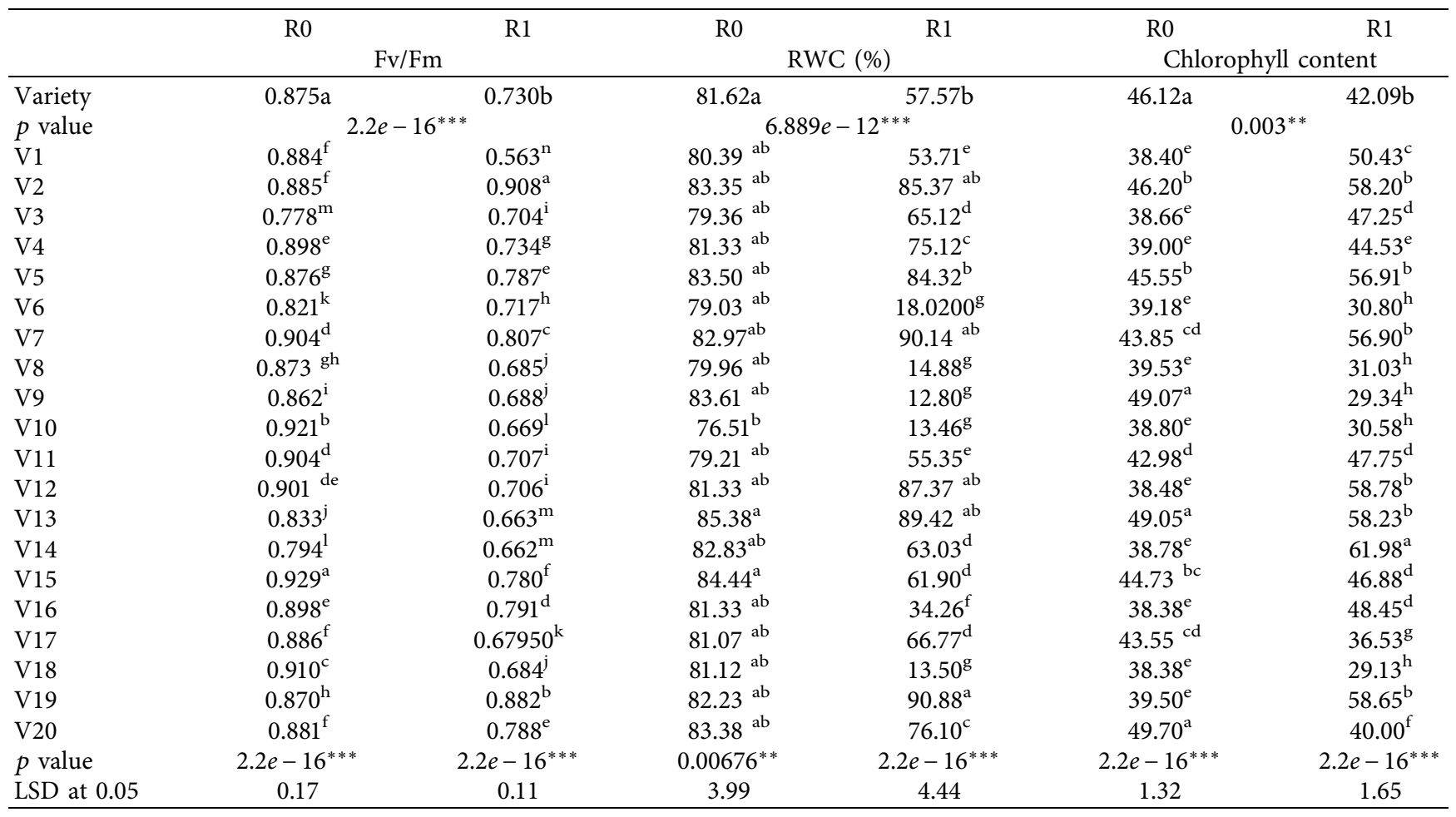

Means with the same letter within a column are not significantly different. V1 to V20 are the 20 varieties used in this study. R1 is the water regime at the vegetative stage.

drought conditions was higher than that of the control plants. There were significant differences $(p<0.05)$ in proline content among the varieties under drought stress during the reproductive stage (Figure 2). The varieties Kpodjiguegue, IT 06K-242-3 (V16), and Gboto (V7) had the highest proline contents under water deficit during the reproductive stage (Table 2).

3.2. Agronomic Traits. There was a significant $(p<0.001)$ difference between the water regimes for all agronomic parameters (Table 3 ). For the stress during the vegetative phase, the number of pods increased as well as the number of days to flowering while for the stress at the reproductive phase, the weight of seeds significantly decreased. However, IT 97K-556-6, KVX 61-1, IT 07K211-1-8, and Kpodjiguegue gave the best performance among genotypes subjected to drought stress at the vegetative phase, which had the best yields with large seeds. IT 06K242-3, Kpodjiguegue, and KVX 61-1 demonstrated high yield with small seeds among the 20 genotypes under water deficit stress at the reproductive phase. IT 06K-242-3 had the biggest seeds among the genotypes subjected to drought conditions at the vegetative phase, while KVX 61-1 and Kpodjiguegue were more productive than others under drought at the reproductive phase (Table 3).

The varieties KVX 61-1, IT 87 S-1390, IT 06K-242-3, IT 07K-211-1-8, and Kpodjiguegue recorded the highest number of pods under drought stress at the vegetative stage, obtaining $24,18,28,25$, and 39 pods, respectively, while
KVX 61-1, IT 87 S-1390, IT 99K-573-2-1, IT 84 S-2246-4, IT 07K-188-49, IT 84 S-2246-4, IT 07K-188-49, IT 06K-242-3, and Kpodjiguegue produced 18, 23, 19, 24, and 30 pods under drought stress at reproductive stage, respectively. On the other hand, IT 97K-556-6, IT 07K-206-1-1, and IT 86 D-1033 had fewer pods under water stress at the vegetative stage, producing 13, 6, and 13 pods, respectively, and KVX 396-18, IT 07K-206-1-1, IT 99K-573-1-1, IT 84E-124, and IT 07K-211-1-8 had 5, 6, 7, 8, and 7 pods, respectively, under water stress at reproductive stress (Figures 2 and 3 ).

3.3. Principal Component Analysis and Ascending Hierarchical Classification. Individual varieties are presented in Supplementary Figure 1, and physiological and agronomic variables are represented in Figure 4. Under water stress at the vegetative stage, the principal component analysis indicated that the PC1 explained most of the variation observed in the traits and accounted for $42.14 \%$ of the variation. The PC 1 comprises individual varieties KVX 61-1 (V2), IT 07K-188-49 (V15), and IT 99K-573-2-1 (V5) on the lower right portion of the graph which is characterized by a strongly positive coordinate on the axis while varieties such as IT 84 S-2246-4 (V8), IT 99K-573-1-1 (V10), IT 07K-2061-1 (V9), and IT 86 D-1033 (V18) on the lower left of the graph are characterized by a strongly negative coordinate on the axis (Figure 4). KVX 61-1 (V2), Gboto (V7), IT 07K-18849 (V15), and IT 99K-573-2-1 (V5) are characterized by (i) high values for the variables $F_{v-} F_{m}, F_{v}$, RWC, Chl_C, and $F_{m}$ and (ii) low values for the variable Fo while the individual 


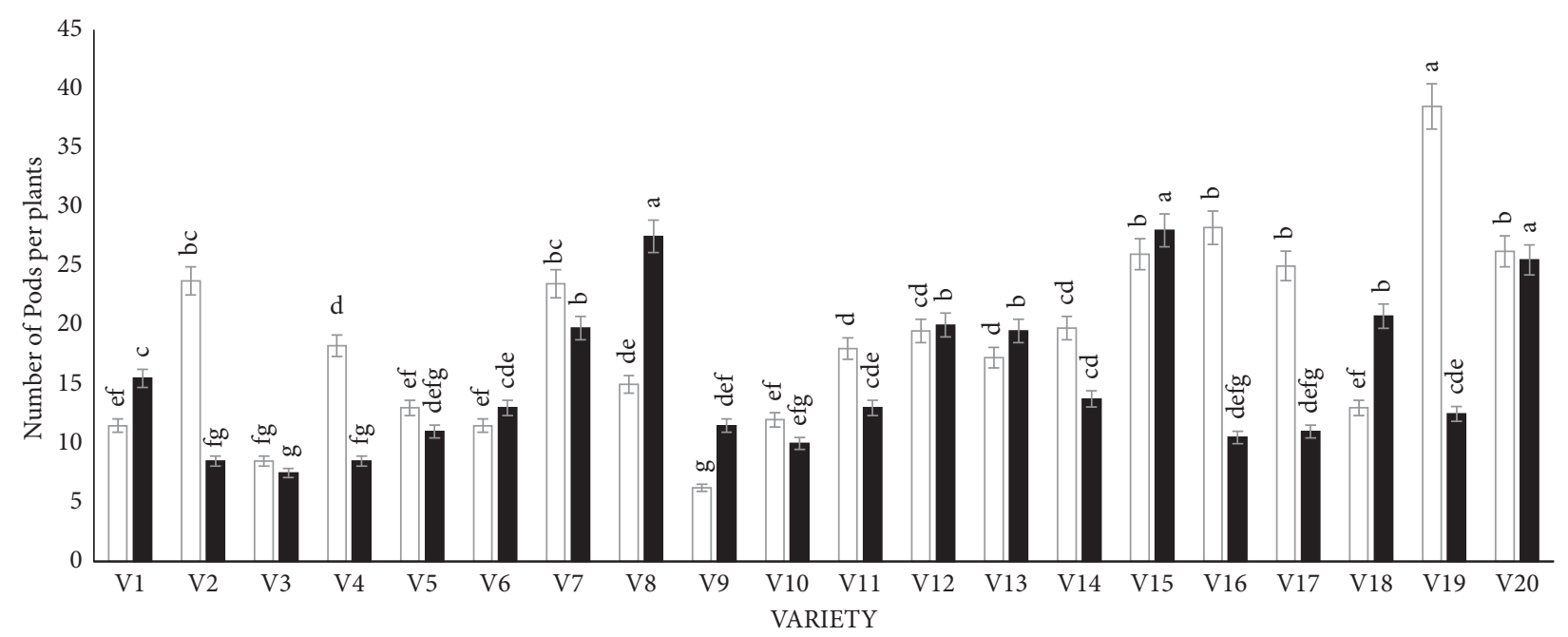

REGIME

$\square \mathrm{R} 1$

- R0

FIGURE 2: Effect of drought stress on the number of pods at the vegetative stage.

TABLE 2: Average physiological parameters under drought stress at reproductive phase.

\begin{tabular}{|c|c|c|c|c|c|c|c|c|}
\hline & \multirow[t]{2}{*}{ R0 } & \multirow[t]{2}{*}{$\mathrm{R} 2$} & \multirow{2}{*}{\multicolumn{2}{|c|}{ RWC (\%) }} & \multirow{2}{*}{\multicolumn{2}{|c|}{$\begin{array}{cc}\text { R0 } & \mathrm{R} 2 \\
\text { Chlorophyll content }\end{array}$}} & \multirow{2}{*}{\multicolumn{2}{|c|}{$\begin{array}{lc}\text { R0 } & \text { R2 } \\
\text { Proline (mg/g. MS) }\end{array}$}} \\
\hline & & & & & & & & \\
\hline Variety & $0.742 \mathrm{a}$ & $0.695 b$ & $81.76 a$ & $49.76 b$ & $42.29 \mathrm{a}$ & $39.18 b$ & $25.71 \mathrm{a}$ & $28.25 \mathrm{a}$ \\
\hline$p$ value & \multicolumn{2}{|c|}{$1.641 e-13^{* * *}$} & \multicolumn{2}{|c|}{$2.2 e-16^{* * *}$} & \multicolumn{2}{|c|}{$0.03879^{*}$} & \multicolumn{2}{|c|}{$0.0895 \mathrm{NS}$} \\
\hline V1 & $0.724^{\mathrm{g}}$ & $0.683^{\mathrm{i}}$ & $81.90^{\mathrm{ab}}$ & $14.05^{\mathrm{h}}$ & $38.40^{\mathrm{e}}$ & $48,43^{\mathrm{a}}$ & $20.49^{\text {ef }}$ & $23.53^{\text {bcdef }}$ \\
\hline $\mathrm{V} 2$ & $0.769^{\mathrm{ab}}$ & $0.755^{\mathrm{c}}$ & $83.34^{\mathrm{ab}}$ & $85.48^{\mathrm{a}}$ & $46.20^{\mathrm{b}}$ & $37,10^{c}$ & $26.27^{\mathrm{cd}}$ & 25.24 bcdef \\
\hline V3 & $0.737^{\mathrm{e}}$ & $0.705^{\mathrm{d}}$ & $79.51^{\mathrm{ab}}$ & $15.48^{\mathrm{h}}$ & $38.66^{\mathrm{e}}$ & $37.40^{c}$ & $19.79^{\text {ef }}$ & $20.31^{\text {cdef }}$ \\
\hline V4 & $0.720^{\mathrm{g}}$ & $0.601^{\mathrm{m}}$ & $82.02^{\mathrm{ab}}$ & $72.41^{\mathrm{b}}$ & $39.00^{\mathrm{e}}$ & $38.03^{\mathrm{c}}$ & $18.05^{\mathrm{f}}$ & 17.74 def \\
\hline V5 & $0.746^{\mathrm{d}}$ & $0.757^{\mathrm{C}}$ & $83.60^{\mathrm{ab}}$ & $79.97^{\mathrm{a}}$ & $45.55^{\mathrm{b}}$ & $40.45^{b c}$ & $27.76^{\mathrm{c}}$ & $32.72 \mathrm{bc}$ \\
\hline V6 & $0.713^{\mathrm{h}}$ & $0.697^{\mathrm{e}}$ & $78.00^{\mathrm{ab}}$ & $12.028^{\mathrm{h}}$ & $39.18^{\mathrm{e}}$ & $34.23^{\mathrm{d}}$ & $20.48^{\text {ef }}$ & 16.81 ef \\
\hline V7 & $0.767^{\mathrm{b}}$ & $0.683^{\mathrm{i}}$ & $82.37^{\mathrm{ab}}$ & $58.95^{\mathrm{c}}$ & $43.85^{\mathrm{cd}}$ & $49.85^{\mathrm{a}}$ & $38.44^{\mathrm{a}}$ & $37.06^{\mathrm{ab}}$ \\
\hline V8 & $0.747^{\mathrm{d}}$ & $0.636^{1}$ & $79.97^{\mathrm{ab}}$ & $84.25^{\mathrm{a}}$ & $39.53^{\mathrm{e}}$ & $41.65^{\mathrm{b}}$ & $20.51^{\text {ef }}$ & $21.31^{\mathrm{cdef}}$ \\
\hline V9 & $0.770^{\mathrm{ab}}$ & $0.674^{j}$ & $83.06^{\mathrm{ab}}$ & $16.17^{\mathrm{h}}$ & $49.07^{\mathrm{a}}$ & $49.85^{\mathrm{a}}$ & $38.17^{\mathrm{a}}$ & $31.70^{\mathrm{bcd}}$ \\
\hline V10 & $0.762^{\mathrm{c}}$ & $0.684^{\mathrm{hi}}$ & $76.02 \mathrm{~b}$ & $47.02^{\mathrm{e}}$ & $38.80^{\mathrm{e}}$ & $40.43^{b c}$ & $27.07^{\mathrm{c}}$ & $33.01^{b c}$ \\
\hline V11 & $0.749^{\mathrm{d}}$ & $0.664^{\mathrm{k}}$ & $79.22^{a b}$ & $82.32^{\mathrm{a}}$ & $42.98^{\mathrm{d}}$ & $40.60^{b c}$ & $26.14^{\mathrm{cd}}$ & $21.05^{\text {cdef }}$ \\
\hline V12 & $0.722^{\mathrm{g}}$ & $0.693^{\mathrm{f}}$ & $81.78^{a b}$ & $36.16^{\mathrm{f}}$ & $38.48^{\mathrm{e}}$ & $40.63^{b c}$ & $23.35^{\text {de }}$ & 29.99 bcde \\
\hline V13 & $0.748^{\mathrm{d}}$ & $0.707^{\mathrm{d}}$ & $84.88^{\mathrm{a}}$ & $15.32^{\mathrm{h}}$ & $49.05^{\mathrm{a}}$ & $50.33^{\mathrm{a}}$ & $28.39^{c}$ & $28.53^{\text {bcdef }}$ \\
\hline V14 & $0.725^{\mathrm{g}}$ & $0.689^{\mathrm{g}}$ & $83.67^{\mathrm{ab}}$ & $21.66^{\mathrm{g}}$ & $38.78^{\mathrm{e}}$ & $40.50^{\mathrm{bc}}$ & $18.30^{\mathrm{f}}$ & 29.17 bcde \\
\hline V15 & $0.772^{\mathrm{a}}$ & $0.760^{\mathrm{b}}$ & $84.69^{\mathrm{a}}$ & $83.80^{\mathrm{a}}$ & $44.73^{b c}$ & $48.60^{\mathrm{a}}$ & $31.08^{\mathrm{b}}$ & $36.73^{\mathrm{ab}}$ \\
\hline V16 & $0.714^{\mathrm{h}}$ & $0.761^{a b}$ & $82.08^{a b}$ & $85.51^{\mathrm{a}}$ & $38.38^{\mathrm{e}}$ & $40.13^{b c}$ & $27.71^{\mathrm{c}}$ & $45.09^{\mathrm{a}}$ \\
\hline V17 & $0.733^{f}$ & $0.708^{\mathrm{d}}$ & $81.07^{\mathrm{ab}}$ & $11.48^{\mathrm{h}}$ & $43.55^{\mathrm{cd}}$ & $40.50^{b c}$ & $23.25^{\text {de }}$ & $28.64^{\text {bcdef }}$ \\
\hline V18 & $0.750^{\mathrm{d}}$ & $0.686^{\mathrm{h}}$ & $81.03^{\mathrm{ab}}$ & $36.22^{\mathrm{f}}$ & $38.38^{\mathrm{e}}$ & $38.00^{c}$ & $18.72^{\mathrm{f}}$ & $25.95^{\text {bcdef }}$ \\
\hline V19 & $0.713^{\mathrm{h}}$ & $0.763^{\mathrm{a}}$ & $82.24^{\mathrm{ab}}$ & $85.69^{\mathrm{a}}$ & $39.50^{\mathrm{e}}$ & $38.38^{b c}$ & $38.43^{\mathrm{a}}$ & $45.59^{\mathrm{a}}$ \\
\hline V20 & $0.759^{c}$ & $0.599^{\mathrm{m}}$ & $84.88^{\mathrm{a}}$ & $51.32^{\mathrm{d}}$ & $49.70^{a}$ & $50.70^{\mathrm{a}}$ & $21.85^{\mathrm{ef}}$ & $14.90^{\mathrm{f}}$ \\
\hline$p$ value & $2.2 e-16^{* * *}$ & $2.2 e-16^{* * *}$ & $0.00529^{* * *}$ & $2.2 e-16^{* * *}$ & $2.2 e-16^{* * *}$ & $2.2 e-16^{* * *}$ & $2.2 e-16^{* * *}$ & $3.14 e-09^{* * *}$ \\
\hline LSD at 0.05 & 0.14 & 0.08 & 4.43 & 4.27 & 2.10 & 3.36 & 2.56 & 8.16 \\
\hline
\end{tabular}

Means with the same letter within a column are not significantly different. V1 to V20 are the 20 varieties used in this study. R2 is the water regime at the reproductive stage.

varieties such as IT 84 S-2246-4 (V8), IT 99K-573-1-1 (V10), IT 07K-206-1-1 (V9), and IT 86 D-1033 (V18) are characterized by low values for the variables RWC, Chl_C, Har_T, and DFL.

The PC 2 particularly distinguishes individuals such as IT 86 D-888 (V6) V14, V4, and Kpodjiguegue (V19) on the upper side of the graph. The individual varieties such as IT 86 D-888 and IT 87 S-1390 are characterized by low values for the variables Fv_Fm and Fv_Fo, whereas Kpodjiguegue (V19) is characterized by high values for the variables number of pods and Yield. 
TABLE 3: Agronomic performance of cowpea varieties under drought stress at both vegetative and reproductive stages.

\begin{tabular}{|c|c|c|c|c|c|c|c|c|c|}
\hline \multirow{2}{*}{ Variety } & \multicolumn{3}{|c|}{ Days to flowering } & \multicolumn{3}{|c|}{ Yield per plant $(\mathrm{kg} / \mathrm{ha})$} & \multicolumn{3}{|c|}{ Weight of 100 grains (g) } \\
\hline & $\mathrm{RO}$ & $\mathrm{R} 1$ & $\mathrm{R} 2$ & $\mathrm{RO}$ & $\mathrm{R} 1$ & $\mathrm{R} 2$ & $\mathrm{RO}$ & $\mathrm{R} 1$ & $\mathrm{R} 2$ \\
\hline$\overline{\mathrm{V} 1}$ & $41.25^{\mathrm{bcde}}$ & $54.75^{\mathrm{c}}$ & $42.00^{\mathrm{bcd}}$ & $361.73^{\mathrm{cd}}$ & $303.50^{\text {cdefg }}$ & $279.59^{\text {efgh }}$ & $14.77^{\mathrm{c}}$ & $12.54^{\mathrm{c}}$ & $12.79^{\text {efg }}$ \\
\hline V2 & $36.50^{\mathrm{e}}$ & $59.50^{\mathrm{abc}}$ & $51.50^{\mathrm{a}}$ & $344.62^{\text {cde }}$ & $425.66^{c}$ & $442.02^{\mathrm{c}}$ & $14.66^{\mathrm{c}}$ & $15.17^{\mathrm{b}}$ & $15.61^{\mathrm{a}}$ \\
\hline V3 & $49.25^{\mathrm{a}}$ & $54.75^{\mathrm{c}}$ & $37.00^{\text {de }}$ & $251.08^{f}$ & $294.69^{\text {defg }}$ & $200.25^{\mathrm{h}}$ & $14.71^{\mathrm{c}}$ & $12.52^{\mathrm{c}}$ & $12.73^{\text {efg }}$ \\
\hline V4 & $49.00^{\mathrm{a}}$ & $49.25^{\mathrm{d}}$ & $37.25^{\mathrm{de}}$ & $169.58^{\mathrm{g}}$ & $372.78^{\text {cdefg }}$ & $270.90^{\text {efgh }}$ & $10.54^{\mathrm{g}}$ & $10.97^{\mathrm{e}}$ & $9.87^{j}$ \\
\hline V5 & $43.50^{\mathrm{abcd}}$ & $58.50^{\mathrm{abc}}$ & $43.75^{\mathrm{b}}$ & $384.69^{\mathrm{bcd}}$ & $400.97^{\text {cde }}$ & $371.68^{\mathrm{cde}}$ & $15.24^{\mathrm{c}}$ & $14.19^{\mathrm{b}}$ & $13.62^{\text {cde }}$ \\
\hline V6 & $48.50^{\mathrm{a}}$ & $37.75^{\text {hi }}$ & $37.50^{\text {cde }}$ & $275.03^{\text {ef }}$ & 278.22 efg & $256.24^{\mathrm{fgh}}$ & $11.79^{\mathrm{f}}$ & $14.67^{\mathrm{b}}$ & $13.04^{\mathrm{ef}}$ \\
\hline V7 & $35.00^{\mathrm{e}}$ & $62.00^{\mathrm{a}}$ & $42.25^{\mathrm{bcd}}$ & $633.62^{\mathrm{a}}$ & $518.14^{\mathrm{b}}$ & $325.48^{\text {defg }}$ & $16.54^{\mathrm{b}}$ & $14.78^{\mathrm{b}}$ & $14.19^{\text {cd }}$ \\
\hline V8 & $48.00^{\mathrm{a}}$ & $38.25^{\text {ghi }}$ & $43.50^{\mathrm{b}}$ & $383.39^{\mathrm{bcd}}$ & $332.99^{\text {cdefg }}$ & $398.92^{\mathrm{cd}}$ & $12.57^{\text {ef }}$ & $12.17^{\mathrm{cd}}$ & $11.50^{\mathrm{hi}}$ \\
\hline V9 & $36.25^{\mathrm{e}}$ & $44.25^{\mathrm{ef}}$ & $36.00^{\mathrm{e}}$ & $451.18^{\mathrm{b}}$ & $265.60^{\mathrm{fg}}$ & $228.23^{\mathrm{gh}}$ & $17.36^{\mathrm{a}}$ & $16.89^{\mathrm{a}}$ & $14.26^{\mathrm{cd}}$ \\
\hline V10 & $44.75^{\mathrm{abc}}$ & $37.50^{\mathrm{hi}}$ & $41.00^{\text {bcde }}$ & $414.10^{\mathrm{bc}}$ & $260.49^{g}$ & $250.30^{\mathrm{fgh}}$ & $16.30^{\mathrm{b}}$ & $14.31^{\mathrm{b}}$ & $13.42^{\mathrm{de}}$ \\
\hline V11 & $45.00^{\mathrm{abc}}$ & $45.75^{\mathrm{e}}$ & $39.75^{\text {bcde }}$ & $333.07^{\text {cde }}$ & $347.46^{\text {cdefg }}$ & $338.65^{\mathrm{def}}$ & $12.03^{\mathrm{f}}$ & $12.78^{\mathrm{c}}$ & $11.13^{\mathrm{i}}$ \\
\hline V12 & $37.25^{\mathrm{e}}$ & $59.50^{\mathrm{abc}}$ & $39.25^{\text {bcde }}$ & $410.21^{b c}$ & $398.06^{\text {cde }}$ & $301.61^{\text {efgh }}$ & $13.20^{\mathrm{de}}$ & $14.37^{\mathrm{b}}$ & $15.18^{\mathrm{ab}}$ \\
\hline V13 & $38.75^{\text {de }}$ & $56.00^{\mathrm{bc}}$ & $38.75^{\text {bcde }}$ & $416.54^{b c}$ & $422.28^{c}$ & $255.69^{\mathrm{fgh}}$ & $16.32^{\mathrm{b}}$ & $14.64^{\mathrm{b}}$ & $14.26^{\mathrm{cd}}$ \\
\hline V14 & 38.50 de & $41.00^{\mathrm{efgh}}$ & $42.75^{\mathrm{bcd}}$ & $272.75^{\mathrm{ef}}$ & $334.80^{\text {cdefg }}$ & $305.43^{\text {efgh }}$ & $12.39^{\mathrm{f}}$ & $14.35^{\mathrm{b}}$ & $11.58^{\mathrm{hi}}$ \\
\hline V15 & $35.75^{\mathrm{e}}$ & $43.00^{\text {efg }}$ & $50.00^{\mathrm{a}}$ & $581.88^{\mathrm{a}}$ & $387.33^{\mathrm{cdef}}$ & $541.30^{\mathrm{b}}$ & $14.57^{\mathrm{c}}$ & $15.38^{\mathrm{b}}$ & $12.05^{\mathrm{ghi}}$ \\
\hline V16 & $45.00^{\mathrm{abc}}$ & 44.50 ef & $50.00^{\mathrm{a}}$ & $357.09^{\mathrm{cd}}$ & $407.42^{\mathrm{cd}}$ & $552.86^{\mathrm{b}}$ & $13.71^{\mathrm{d}}$ & $17.59^{\mathrm{a}}$ & $14.53^{\mathrm{bc}}$ \\
\hline V17 & $47.50^{\mathrm{a}}$ & $39.75^{\text {fghi }}$ & $39.25^{\text {bcde }}$ & 313.53 def & $410.88^{\mathrm{cd}}$ & $213.78^{h}$ & $16.19^{\mathrm{b}}$ & $14.35^{\mathrm{b}}$ & $13.60^{\text {cde }}$ \\
\hline V18 & $46.75^{\mathrm{ab}}$ & $35.25^{\mathrm{i}}$ & $43.25^{\mathrm{bc}}$ & $382.96^{\mathrm{bcd}}$ & $279.13^{\mathrm{efg}}$ & $263.99^{\text {fgh }}$ & $12.25^{\mathrm{f}}$ & $12.15^{\mathrm{cd}}$ & $12.29^{\mathrm{fgh}}$ \\
\hline V19 & $40.50^{\text {cde }}$ & $60.50^{\mathrm{ab}}$ & $47.75^{\mathrm{a}}$ & $178.63^{\mathrm{g}}$ & $640.62^{\mathrm{a}}$ & $745.92^{\mathrm{a}}$ & $8.52^{\mathrm{h}}$ & $11.34^{\mathrm{de}}$ & $13.68^{\text {cde }}$ \\
\hline V20 & $39.50^{\text {cde }}$ & $39.75^{\text {fghi }}$ & $48.25^{\mathrm{a}}$ & $463.33^{\mathrm{b}}$ & $299.65^{\text {cdefg }}$ & $296.38^{\text {efgh }}$ & $9.90^{\mathrm{g}}$ & $9.51^{\mathrm{f}}$ & $10.11^{\mathrm{j}}$ \\
\hline$p$ value & $1.386 e-14^{* * *}$ & $2.2 e-16^{* * *}$ & $7.08 e-16^{* * *}$ & $2.2 e-16^{* * *}$ & $1.302 e-14^{* * *}$ & $2.2 e-16^{* * *}$ & $2.2 e-16^{* * *}$ & $2.2 e-16^{* * *}$ & $2.2 e-16^{* * *}$ \\
\hline $\begin{array}{l}\text { LSD at } \\
0.05\end{array}$ & 3.91 & 3.47 & 3.52 & 54.58 & 73.40 & 64.85 & 0.67 & 0.73 & 0.71 \\
\hline
\end{tabular}

Means with the same letter within a column are not significantly different.

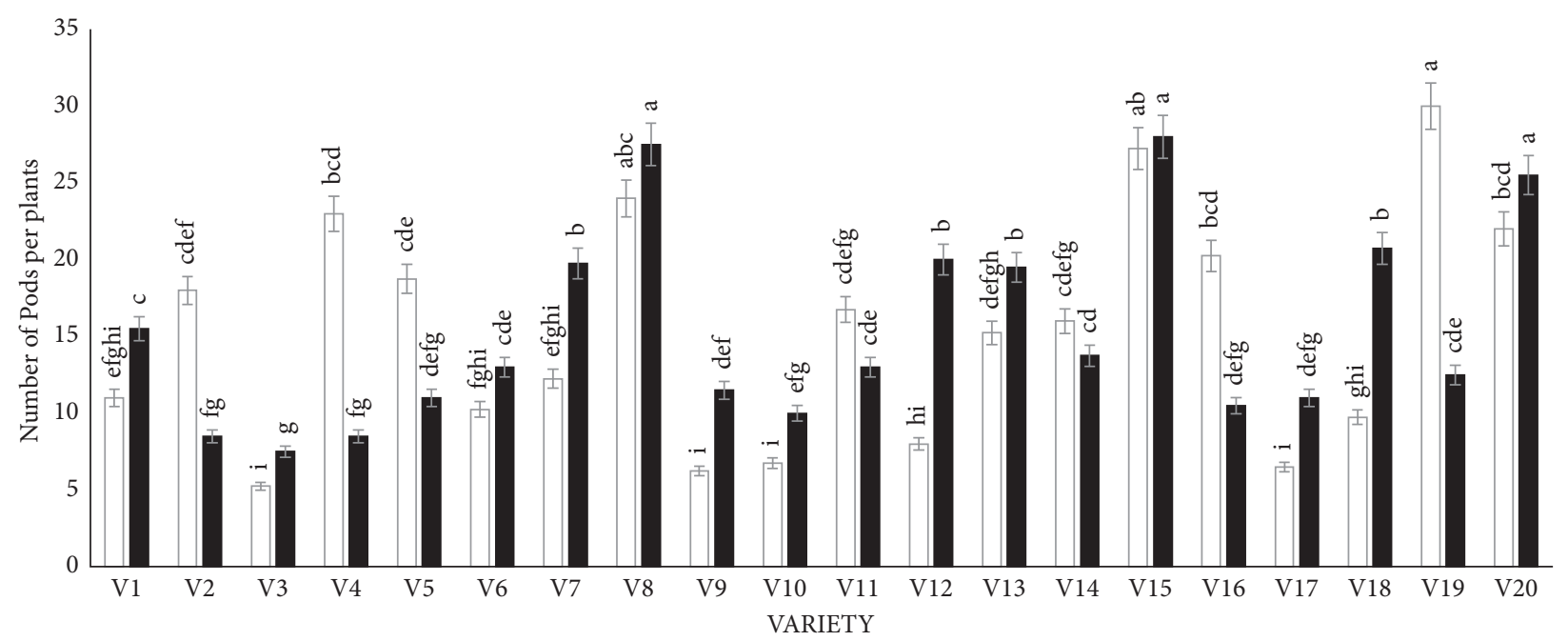

REGIME

$\square \mathrm{R} 2$

- R0

FIgURE 3: Effect of drought stress on the number of pods at the reproductive stage.

Cluster 1 includes IT 86 D-888 (V6), IT 84 S-2246-4 (V8), IT 07K-206-1-1 (V9), IT 99 K-573-1-1 (V10), and IT 86 D-1033 (V18), which are characterized by (i) high values for the variable Fo and (ii) low values for the variables RWC, Fv_Fm, number of pods (No. P), Yield, Har_T, Chl_C, Fv_Fo, and days to flowering (DFL) (Supplementary Figure 2 and Figure 5). Cluster 2 comprises IT 87 S-1390 (V4), which is characterized by low values for the variables Fo and
Fm (Supplementary Figure 2 and Figure 5). Cluster 3 is made of individuals such as KVX 61-1 (V2), IT 99K-573-2-1 (V5), Gboto (V7), IT 07K-188-49 (V15), and Kpodjiguegue (V19). This cluster is characterized by high values for the variables Fv, Fm, Yield, No. P, Fv_Fm, DFL, and Chl_C (Supplementary Figures 2 and Figure 5).

Under water stress at the reproductive stage, the principal component analysis indicated that the PC1 explained 


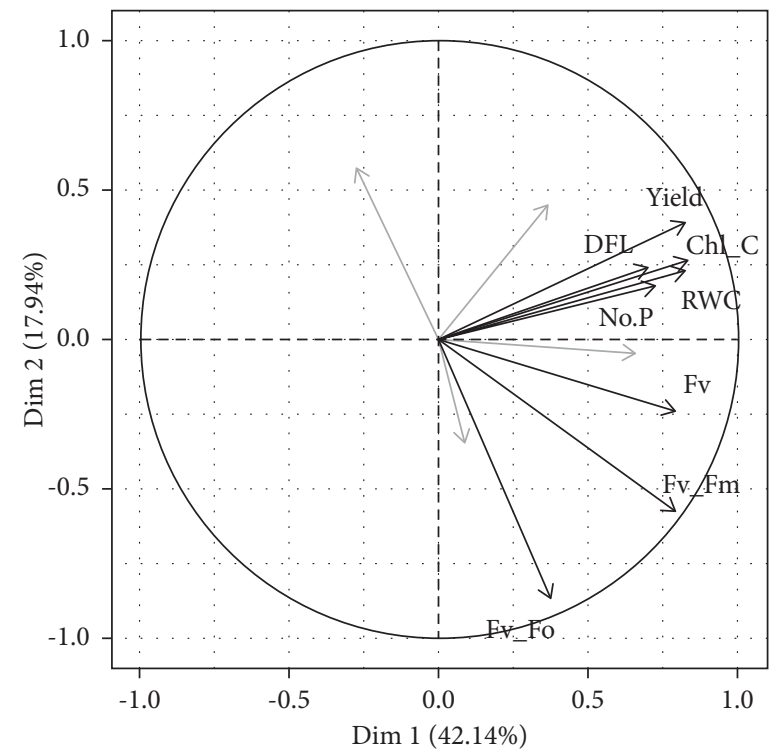

FIGURE 4: Individual variables under drought stress at the vegetative stage. DFL= days to flowering, RWC= relative water content, Chl_C $=$ chlorophyll content, No.P = number of pods, Fo is the minimal fluorescence after dark adaptation, Fm is the maximal fluorescence, $\mathrm{Fv} / \mathrm{Fm}=(\mathrm{Fm}-\mathrm{Fo}) / \mathrm{Fm}$ is the maximum quantum yield, and $\mathrm{Fv} / \mathrm{Fo}=(\mathrm{Fm}-\mathrm{Fo}) / \mathrm{Fo}$ is a more sensitive plant stress detector than $\mathrm{Fv} / \mathrm{Fm}$.
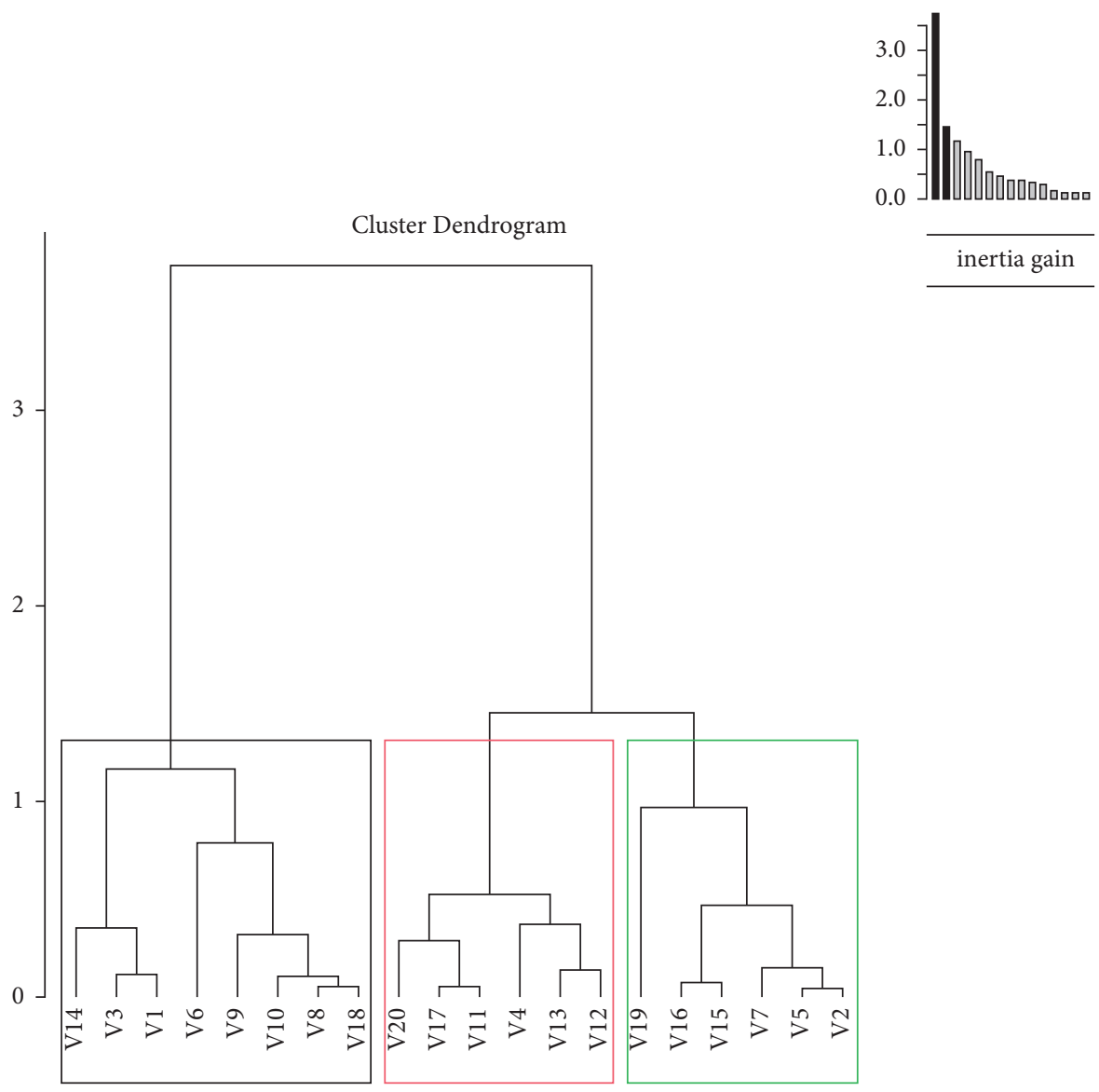

inertia gain

Figure 5: Hierarchical tree of individual varieties under drought stress at vegetative stage.

most of the variation observed in the traits and accounted for $54.28 \%$ (Supplementary Figure 3). Dimension 1 includes individuals such as IT 07K-188-49 (V15), Kpodjiguegue
(V19), IT 06K-242-3 (V16), and KVX 61-1 (V2) on the right of the graph and individuals such as KVX 396-18 (V3), IT 07K-211-1-8 (V17), and IT 93K-452-1 (V13) on the left of 
the graph. IT 07K-188-49 (V15), Kpodjiguegue (V19), IT 06 K-24-3 (V16), and KVX 61-1 (V2) are characterized by high values for the variables DFL, Yield, Fv_Fo, Fv_Fm, Proli, Fv, RWC, and Fm while the individuals KVX 396-18 (V3), IT 07K-211-1-8 (V17), and IT 93K-452-1 (V13) are characterized by low values for the variables Fm, Fv, Fv_Fm, Har_T, Fv_Fo, RWC, and No.P (Figure 6).

Hierarchical tree and ascending hierarchical classification of the individuals under water stress at the reproductive stage are presented in Figure 7 and Supplementary Figure 4. Cluster 1 is made of individuals such as KVX 396-18 (V3), IT 93K-452-1 (V13), and IT 07K-211-1-8 (V17), which are characterized by low values for the variables Fm, Fv_Fm, Fv, Fv_Fo, Fo, and RWC. Cluster 2 comprises IT 87 S-1390 (V4), IT 86 D-888 (V6), IT 84 D-449 (V11), and Tawa (V20). This cluster is characterized by (i) high values for the variable Fo and (ii) low values for the variable Yield. Cluster 3 includes KVX 61-1 (V2), IT 07K-188-49 (V15), IT 06K-242-3 (V16), and Kpodjiguegue (V19). This group is characterized by high values for the variables Yield, DFL, Fv_Fo, RWC, Chl_C, Proli, No.P, Fv_Fm, and Fv.

\section{Discussion}

Water stress affects physiological parameters in vegetative and reproductive stages. Chlorophyll fluorescence represents the quantitative measure of the photosynthetic performance of plants under stress conditions. It is a good tool for the identification of genotypes tolerant to abiotic stress especially drought stress. Chlorophyll fluorescence measures the activity of photosystem II, which has a large measurement variability, i.e., water photolysis into gaseous oxygen and hydrogen ion, electron release, and production of energy compared to photosystem I $[35,36]$. This study made it possible to compare the results of chlorophyll fluorescence obtained under water stress conditions and nonstressed conditions. The values of the chlorophyll fluorescence parameters recorded are lower under water deficit conditions than those under unstressed conditions as shown in Tables 1 and 2. There was a significant difference in the photosynthetic yield between the two regimes at vegetative and reproductive stages. This can be explained by the negative effect of water deficit on the photosynthetic apparatus of the genotypes studied. These results agree with those of Schreiber and Berry [37] and Al-Khatib and Paulsen [38] who indicated that the presence of stress causes a decrease in maximum fluorescence (Fm) and therefore a decrease in $\mathrm{Fv}$ / Fm, thus reducing photosynthesis. Bukhov and Mohanty [39], Guissé et al. [40], Lazár et al. [41], and Yamori et al. [42] reported that water stress causes a decline in the rate of $\mathrm{O}_{2}$ release, electron transport, and the $\mathrm{Fv} / \mathrm{Fm}$ ratio which is explained by the increase of Fo due to the increase in leaf temperature and decrease in Fm. This corroborates our results. The reduction in the chlorophyll content in stressed plants can be explained by the fact that chlorophylls are more degraded than synthesized in the latter while in unstressed plants these pigments are synthesized. Moreover, according to Bousba et al. [43], the decline in chlorophyll content under water deficit is the consequence of the

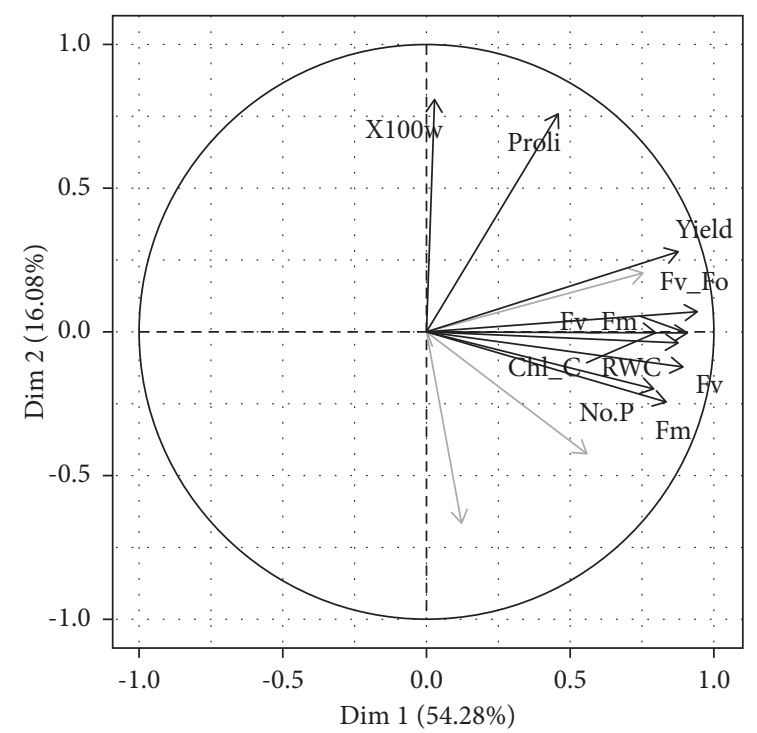

FIgURE 6: Variables factor map (PCA) under water stress at the reproductive stage. Proli $=$ proline, $\mathrm{DFL}=$ days to flowering, RWC $=$ relative water content, Chl_C $=$ chlorophyll content, No.P = number of pods, Fo is the minimal fluorescence after dark adaptation, $\mathrm{Fm}$ is the maximal fluorescence, $\mathrm{Fv} / \mathrm{Fm}=(\mathrm{Fm}-\mathrm{Fo}) / \mathrm{Fm}$ is the maximum quantum yield, and $\mathrm{Fv} / \mathrm{Fo}=(\mathrm{Fm}-\mathrm{Fo}) / \mathrm{Fo}$ is a more sensitive plant stress detector than Fv/Fm.

reduction in the opening of the stomata to avoid water losses through transpiration, and this reduction of stomata opening also leads to the decrease in the atmospheric $\mathrm{CO}_{2}$ necessary for photosynthesis.

The relative water content is a parameter indicating the water status of a plant. In the present study, water deficit had a significant effect on the RWC of stressed plants. The unavailability of water caused the stressed plants to lose their water and their turgidity which was illustrated through the lower values of the recorded RWC. Our results are in agreement with those on cowpea [44-47]. Lobato et al. [45] studied the effect of the water deficit on cowpea and noticed that the RWC decreases by $25.7 \%$ while the control value remains between $88 \%$ and $91 \%$. Anyia and Herzog [48] noticed an average reduction of $12.2 \%$ in leaf RWC in stressed plants compared to the control and that the magnitude of reduction was cultivar-dependent. Lobato et al. [46] observed a significant decrease of more than $31 \%$ in the RWC in two cowpea varieties under water stress. Meftah [47] noted a reduction of $14.41 \%$ under moderate stress and $23.03 \%$ under severe stress.

Under water stress conditions, the agronomic traits were significantly affected especially when there is water stress at the beginning of the inflorescence. These results confirm those of previous work by $[48,49]$ who showed that water stress negatively and significantly affected the flowering and filling of cowpea pods, which considerably reduced yield. The severity of this stress is because it affects parameters related to seed formation including photosynthesis and translocation of assimilates [49-51]. Ahmed and Suliman [52] observed a significant reduction of over $40 \%$ under water deficit. The same result was obtained by Dadson et al. 

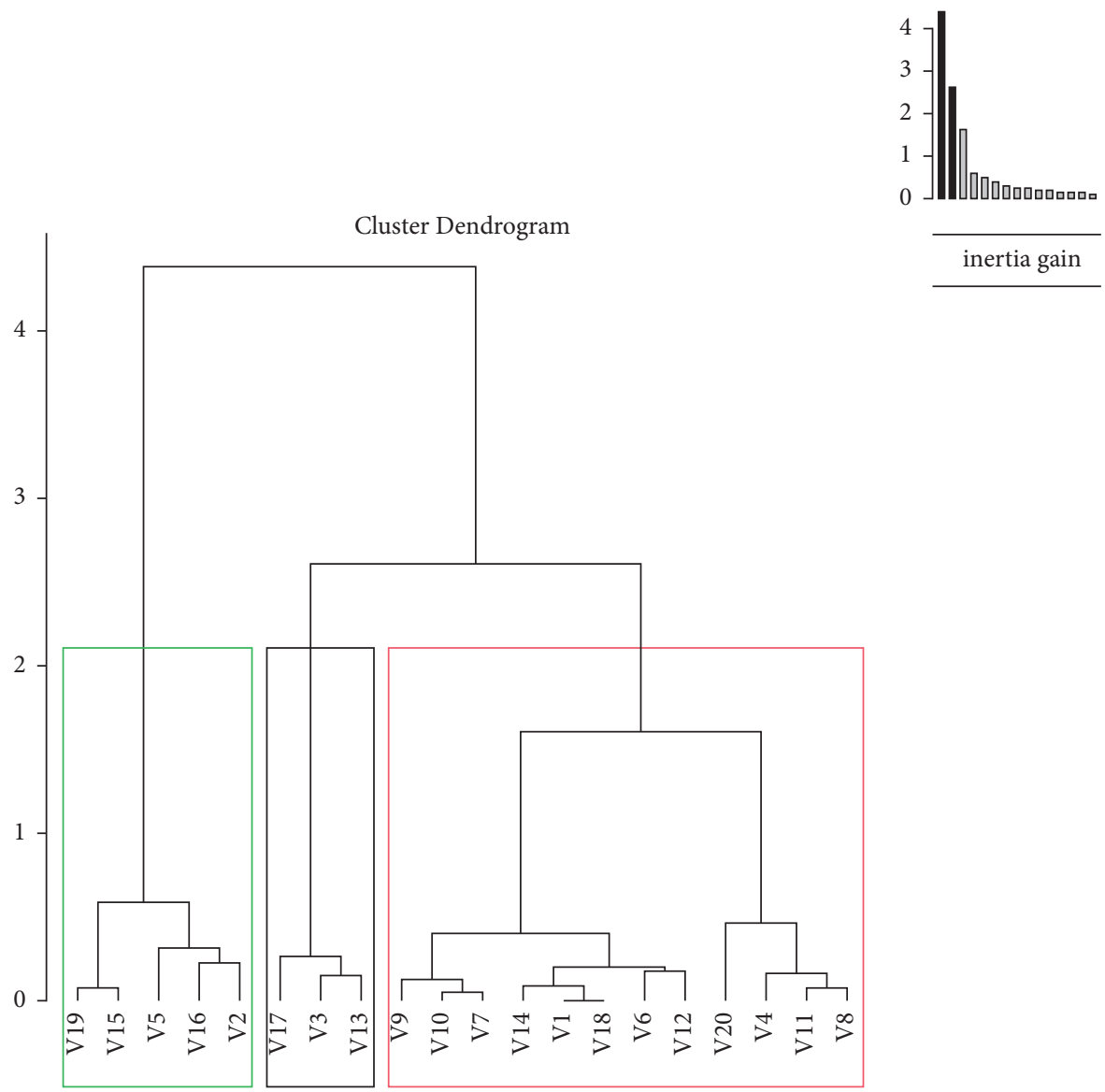

FIgURE 7: Hierarchical tree under water stress at the reproductive stage.

[29] in ten cultivars of cowpea under water constraints. Water stress affects the growth and development of plants and reduces seed yield. Lisar et al. [53] reported that, in plants under water stress, during the setting of flowers and pod formation stages, the yield reduction was 50\% lower than the control plants. According to Chiulele et al. [54], drought during the formation of flowers and pods influences yields negatively. Water stress affects seed development, production, or distribution of photoassimilates [49]. Water deficit causes a delay in flowering depending on the species [55]. On the other hand, the stressed plants in the reproductive stage showed a similar trend in days to flowering with controlled plants [56]. Zombré et al. [57] observed that water deficit conditions cause a large number of flower abortions which reduces the yield of plants. Lalsaga et al. [56] explained the reduction in the weight of the seeds by a reduction in the synthesis of photoassimilates necessary for filling the seeds following the unavailability of water for photochemical reactions. This is similar to our observations during the two spells of water stress imposition. Thus, in our study, the more a plant had a long vegetative/development cycle especially the resistant ones [KVX 61-1 (V2), Kpodjiguegue (V19)], the more it showed a large number of pods and thus a high yield. This could also be due to the fact that with a long development cycle there was sufficient time for stressed plants recovery and the regaining of physiological functions indispensable for high productivity.
Proline is a very important osmoprotectant in the life of stressed plants. Proline can protect the integrity of proteins by preventing the aggregation of proteins and thus maintain the stability of the configuration of proteins and enzymes; its biosynthesis is activated during dehydration [58]. Our study showed an increase in the proline content in stressed plants, especially in stress-resistant varieties. Our results corroborate those obtained on beans [59] and cowpea $[45,60]$. The increase in proline content and chlorophyll content results in keeping plant water status and chlorophyll activity.

The cowpea varieties fell into different clusters that equated their yield potentials and stress tolerance. Under drought imposition at the vegetative stage, it was observed that KVX 61-1 (V2), Gboto (V7), IT 07K-188-49 (V15), and IT 99 K-573-2-1 (V5) shared high values for Fv_Fm, Fv, RWC, Chl_C, and Fm as the most contributive variables for genotypes dispersion along the first axis. Similarly, in the second axis, IT 86 D-888 (V6) and Kpodjiguegue (V19) are characterized by a strongly positive coordinate on the axis. V6 was characterized by low values of Fv_Fm and Fv_Fo while Kpodjiguegue (V19) was characterized by high values for the variables number of pods and yield as the main contributive factor to drought tolerance in cowpea. The varieties KVX 61-1 (V2), Gboto (V7), IT 07K-188-49 (V15), IT 99K-573-2-1 (V5), IT 06K-242-3 (V16), and Kpodjiguegue (V19) were associated with Fv_Fm, Fv, RWC, Chl_C, Fm, and yield, 
which represent the cluster of higher-yielding and stresstolerant varieties under water deficit at vegetative stage. Santos et al. [61] reported a strong contribution of the pod and grain-related components, namely, pod dry weight, along the PC1 axis, for the screening of drought-tolerant cowpea genotypes at the seedling stage. Under water deficit at reproductive stage, IT 07 K-188-49 (V15), Kpodjiguegue (V19), IT 06K-242-3 (V16), and KVX 61-1 (V2) were characterized by high values for DFL, Yield, Fv_Fo, Fv_Fm, Proli, Fv, RWC, and Fm. Thus, high yield, high proline content, high relative water content, Fv/Fm, and days to flowering significantly contributed to the drought tolerance of these varieties used in this study. The drought stress attributes such as yield, proline content, relative water content, and $\mathrm{Fv} / \mathrm{Fm}$ were correlated with the varieties KVX 61-1 (V2), IT 07K-188-49 (V15), IT 06K-242-3 (V16), IT 99K-573-2-1 (V5), and Kpodjiguegue (V19), which represent the cluster of higheryielding and stress-tolerant varieties under water deficit at reproductive stage. Overall, the dispersion of cowpea varieties in the PCA reflected the groupings based on their physiological and agronomic responses to drought stress effects.

\section{Conclusion}

The varieties Kpodjiguegue, Gboto, and KVX 61-1 gave the highest grain yields and were found to be the most drought-tolerant under water stress at the vegetative stage and the varieties Kpodjiguegue, IT 06K-242-3, IT 07K-188-49, and KVX 61-1 gave the highest grain yields and were found to be the most drought-tolerant under water deficit at the reproductive stage. To have more efficient genotypes in the condition of water stress, we must initiate crosses between the different tolerant genotypes and between tolerant genotypes and those sensitive to water stress to combine the different mechanisms of tolerance.

\section{Abbreviations \\ CCI: Chlorophyll concentration index \\ ANOVA: Analysis of variance \\ PCA: Principal component analysis \\ RWC: Relative water content \\ FW: $\quad$ Fresh weight \\ DW: Dry weight \\ WFC: Weight of the full turgor \\ Fv/Fm: Photochemical yield.}

\section{Data Availability}

Climatic, physiological, morphological, and agronomic data collected as the findings of this study are included within the article.

\section{Conflicts of Interest}

The authors declare that there are no conflicts of interest.

\section{Authors' Contributions}

VE and AA designed the experiment. CT carried out the fieldwork. CT and IBC conducted laboratory work. CT, VE, and AA performed the statistical analysis and CT drafted the manuscript. VE, AA, and IBC coordinated the study and contributed to the write-up of the manuscript. VE and AA edited the manuscript. All authors read and approved the final manuscript.

\section{Supplementary Materials}

Supplementary Figure 1: individual varieties under drought stress at the vegetative stage. The labeled individuals are those with the higher contribution to the plane construction. Supplementary Figure 2: ascending hierarchical classification of the individuals under drought stress at the vegetative stage. Supplementary Figure 3: individual varieties under drought stress at the reproductive stage. The labeled individuals are those with the higher contribution to the plane construction. Supplementary Figure 4: ascending hierarchical classification of the individuals under water stress at the reproductive stage. (Supplementary Materials)

\section{References}

[1] N. Q. Ng and R. Marechal, "Cowpea taxonomy. origin and germplasm," in Cowpea Research. Production and Utilization, S. R. Singh and K. O. Rachie, Eds., pp. 11-21, John Wiley and Sons Ltd., Hoboken, NJ, USA, 1985.

[2] O. Boukar, N. Belko, S. Chamarthi et al., "Cowpea (Vigna unguiculata): genetics. genomics and breeding," Plant Breeding, vol. 138, pp. 415-424, 2018.

[3] FAO, FAOSTAT Online Statistical Services: Crop Production Data, Food and Agriculture Organization of the United Nation (FAO), Rome, Italy, 2017.

[4] M. Alemu, M. Asfaw, Z. Woldu, B. A. Fenta, and B. Medvecky, "Cowpea (Vigna unguiculata (L.) Walp.) (Fabaceae) landrace diversity in northern Ethiopia," International Journal of Biodiversity and Conservation, vol. 8, no. 11, pp. 297-309, 2016.

[5] E. Kebede and Z. Bekeko, "Expounding the production and importance of cowpea (Vigna unguiculata (L.) Walp.) in Ethiopia," Cogent Food \& Agriculture, vol. 6, no. 1, Article ID 1769805, 2020.

[6] A. S. Langyintuo, J. Lowenberg-DeBoer, M. Faye et al., "Cowpea supply and demand in West and central Africa," Field Crops Research, vol. 82, no. 2-3, 2003.

[7] A. Gbaguidi, P. Assogba, M. Dansi, H. Yedomonhan, and A. Dansi, "Caractérisation agromorphologique des variétés de niébé cultivées au Bénin,” International Journal of Biological and Chemical Sciences, vol. 9, no. 2, pp. 1050-1066, 2013.

[8] MAEP (Ministère de l'Agriculture de l'Elevage et de la Pêche), "Données statistiques des spéculations au Bénin," Science Journal, vol. 4, pp. 60-67, 2012.

[9] J. Abadassi, "Characterization of traditional maize populations cultivated in Benin," International Journal of Biological and Chemical Sciences, vol. 8, no. 2, pp. 434-442, 2014.

[10] OECD (Organization for Economic Co-Operation and Development), "Safety assessment of transgenic organisms in the environment," OECD Consensus Documents, Harmonization 
of Regulatory Oversight in Biotechnology, Vol. 6, OECD Publishing, , Paris, France, 2016.

[11] B. Sibhatu, K. Belete, and T. Tessema, "Effect of cowpea density and nitrogen fertilizer on a sorghum-cowpea intercropping system in kobo, northern Ethiopia," International Journal of Agriculture and Forestry, vol. 5, no. 6, pp. 305-317, 2015.

[12] S. Kyei-Boahen, C. E. N. Savala, D. Chikoye, and R. Abaidoo, "Growth and yield responses of cowpea to inoculation and phosphorus fertilization in different environments," Frontiers in Plant Science, vol. 8, p. 646, 2017.

[13] A. Y. Kamara, L. O. Omoigui, N. Kamai, S. U. Ewansiha, and H. A. Ajeigbe, "Improving cultivation of cowpea in West Africa. In achieving sustainable cultivation of grain legumes volume 2: improving cultivation of particular grain legumes," Burleigh Dodds Series in Agricultural Science, Burleigh Dodds Science Publishing, Cambridge, UK, pp. 1-18, 2018.

[14] T. Stoilova and G. Pereira, "Assessment of the genetic diversity in a germplasm collection of cowpea (Vigna unguiculata (L.) Walp.) using morphological traits," African Journal of Agricultural Research, vol. 8, no. 2, pp. 208-215, 2013.

[15] B. B. Singh, H. A. Ajeigbe, S. A. Tarawali, S. FernandezRivera, and M. Abubakar, "Improving the production and utilization of cowpea as food and fodder," Field Crops Research, vol. 84, pp. 169-177, 2003.

[16] G. Abebe, T. Assefa, H. Harrun, T. Mesfine, and A.-R. M. AlTawaha, "Participatory selection of drought-tolerant maize varieties using mother and baby methodology: a case study in the semiarid zones of the Central Rift valley of Ethiopia," World Journal of Agricultural Sciences, vol. 1, pp. 22-27, 2005.

[17] B. B. Singh, O. L. Chambliss, and B. Sharma, "Recent advances in cowpea breeding," in Advances in Cowpea Research, B. B. Singh, R. Mohan, and K. E. Dashiell, Eds., IITA, Ibadan, Nigeria, 1997.

[18] L. D. Kuykendall, F. M. Hashem, R. B. Dadson, and G. K. Elkan, "Nitrogen fixation," in Encyclopedia of Microbiology, J. Lederberg, Ed., pp. 329-404, Academic Press, Cambridge, MA, USA, 2000.

[19] L. M. V. Martins, G. R. Xavier, F. W. Rangel et al., "Contribution of biological fixation to cowpea: a strategy for improving seed yield in the semi-arid region of Brazil," Biology and Fertility of Soils, vol. 38, pp. 333-339, 2003.

[20] J. T. Turk and E. A. HaIl, "Drought adaptation of cowpea II. Influence of drought on plant water status and relations with seed yield," Agronomy Journal, vol. 72, 1980.

[21] B. Pejić, K. Mačkić, A. Mikić, B. Ćupina, E. Peksen, and S. Antanasović, "Effect of water stress on the yield of cowpea (vigna unguiculata L. Walp.) in temperate climatic conditions," Contemporary Agriculture/Savremena Poljoprivreda, vol. 62, pp. 168-176, 2013.

[22] S. Thiaw, A. E. Hall, and D. R. Parker, "Varietal intercropping and the yields and stability of cowpea production in semiarid Senegal," Field Crops Research, vol. 33, pp. 217-233, 1993.

[23] E. A. Bastos, S. P. Nascimento, E. M. Silva, F. R. Freire, and R. L. Gomide, "Identification of cowpea genotypes for drought tolerance 1," Revista de Ciencias Agronomicas, vol. 42, pp. 100-107, 2021.

[24] S. P. Nascimento, E. A. Bastos, E. C. E. Araujo, F. R. Freire, and E. M. Silva, "Tolerancia ao deficit hidrico em genotipos de feijao-caupi," Revista Brasileira de Engenharia Agrícola e Ambiental, vol. 15, pp. 853-860, 2011.

[25] A. C. M. E. Agbicodo, C. A. Fatokun, S. Muranaka, R. G. F. Visser, and C. G. Linden, "Breeding drought-tolerant cowpea: constraints. accomplishments. and prospects," Euphytica, vol. 167, no. 3, pp. 353-370, 2009.

[26] IPCC, "Climate Change: the physical science basis," in Fourth Assessment Report of the Intergovernmental Panel on Climate Change, S. Solomon, D. Qin, M. Manning et al., Eds., Cambrige University Press, Cambridge, UK, 2007.

[27] B. B. Singh and T. Matsui, "Cowpea varieties for drought tolerance," in Challenges and Opportunities for Enhancing Sustainable Cowpea Production. World Cowpea Conference III Proceedings, C. A. Fatokun, S. A. Tarawali, B. B. Singh, P. M. Kormawa., and M. Tamo, Eds., pp. 287-300, International Institute of Tropical Agriculture, Ibadan, Nigeria, 2002.

[28] E. Hall, "Breeding for adaptation to drought and heat in cowpea," European Journal of Agronomy, vol. 21, pp. 447-454, 2004.

[29] R. B. Dadson, F. M. Hashem, I. Javaid, A. L. Allen, and T. E. Devine, "Effect of water stress on yield of cowpea (Vigna unguiculata L. Walp.) genotypes in the Delmarva region of the United States," Journal of Agronomy and Crop Science, vol. 19, pp. 210-217, 2005.

[30] S. Watanabe, S. Hakoyama, T. Terao, and B. B. Singh, "Evaluation methods for drought tolerance of cowpea," in Advances in Cowpea Research, B. B. Singh, Ed., pp. 87-98, IITA/JIRCAS. IITA, Ibadan, Nigeria, 1997.

[31] Y. Mai-Kodomi, B. B. Singh, O. Myers, J. H. Yopp, P. J. Gibson, and T. Terao, "Two mechanisms of drought tolerance in cowpea," Indian Journal of Genetics and Plant Breeding, vol. 59, no. 3, pp. 309-316, 1999.

[32] A. K. Toudou Daouda, S. Atta, M. M. Inoussa, and Y. Bakasso, "Mécanisme de tolérance à la sécheresse du niébé pendant la phase végétative," Journal of Applied Bioscience, vol. 117, p. 11737, 2017.

[33] N. C. Turner and J. E. Begg, "Plant-water relation and adaptation to stress," in Soil Water and Nitrogen in Mediterranean Type Environment, J. Monteith and C. Webb, Eds., Springer, Berlin, Germany, pp. 97-131, 1981.

[34] L. M. Bates and A. E. Hall, "Stomatal closure with soil water depletion not associated with changes in bulk leaf water status," Oecologia, vol. 50, pp. 62-65, 1981.

[35] G. H. Krause and E. Weis, "Chlorophyll fluorescence and photosynthesis: the basics," Annual Review of Plant Physiology and Plant Molecular Biology, vol. 42, pp. 313249, 1991.

[36] K. Kawakami and J.-R. Shen, "Purification of fully active and crystallizable photosystem II from thermophilic cyanobacteria," Methods in Enzymology, vol. 613, pp. 1-16, 2018.

[37] U. Schreiber and J. A. Berry, "Heat-induced changes of chlorophyll fluorescence in intact leaves correlated with damage of the photosynthetic apparatus," Planta, vol. 136, no. 3, pp. 233-238, 1977.

[38] K. Al-Khatib and G. M. Paulsen, "Mode of high temperature injury to wheat during grain development," Physiologia Plantarum, vol. 61, pp. 363-368, 1984.

[39] N. G. Bukhov and P. Mohanty, "Elevated temperature stress effects on photosystems: characterization and evaluation of nature of heat induced impairments," in Concepts in Photobiology: Photosynthesis and Photomorphogenesis, G. S. Singhal, G. Renger, S. K. Sopory, and K.-D. I. Govindjee, Eds., Springer, Berlin, Germany, pp. 617-648, 1999.

[40] B. Guissé, A. Srivastava, and R. J. Strasser, "The polyphasic rise of the chlorophyll a fluorescence (OKJIP) in heat-stressed leaves," Archives des Sciences, vol. 48, pp. 147-160, 1995.

[41] D. Lazár, P. Ilík, and J. Nauš, “An appearance of K-peak in fluorescence induction depends on the acclimation of barley 
leaves to higher temperatures," Journal of Luminescence, vol. 72-74, pp. 595-596, 1997.

[42] W. Yamori, K. Knoguchi, and I. Terashima, "Temperature acclimation of photosynthesis in spinach leaves: analyses of photosynthetic components and temperature dependencies of photosynthetic partial reactions," Photosynthesis Research, vol. 28, pp. 536-547, 2005.

[43] R. Bousba, N. Ykhlef, and A. Djekoun, "Water use efficiency and flag leaf photosynthetic in response to water deficit of durum wheat (Triticum durum Desf.)," World Journal of Agricultural Sciences, vol. 5, pp. 609-616, 2009.

[44] A. O. Anyia and H. Herzo, "Genotypic variability in drought performance and recovery in cowpea un controlled environment," Journal of Agronomy and Crop Science, vol. 190, pp. 151-159, 2004.

[45] O. Lobato and R. C. L. Costa, "Biochimical and physiological of vigna unguiculata (L.) walp. under water stress during the vegetatie phase," Asian Journal of Plants Sciences, vol. 7, no. 1, pp. 44-49, 2008.

[46] O. Lobato, C. F. Neto, G. G. Santos Filho et al., "Consequence of the water deficit on water relations and symbiosis in Vigna unguiculata cultivars," Plant Soil and Environment, vol. 55, no. 4, pp. 139-145, 2009.

[47] M. Y. Meftah, "Effet du stress hydrique sur le comportement de deux populations de niébé (Vigna unguiculata L.) inoculées par quatre souches rhizobia autochtones. Mémoire en vue de l'obtention du diplôme de magistère et en agronomie," École Nationale Supérieure Agronomique El-Harrach-Alger, vol. 97, 2012.

[48] M. D. L. Leite, J. D. Rodrigues, and J. S. Virgens Filho, “Das Efeitos do déficit hídrico sobre a sultura do caupi, cvEMAPA-821. III-Produção," Revue de l'Agriculture, vol. 75, no. 9-20, 2000.

[49] R. M. S. Mendes, J. A. Távora, F. José, J. B. Pitombeira, and J. M. Nogueira, "Source-sink relationships in cowpea under drought stress," Revista Ciência Agronômica, vol. 38, pp. 95-103, 2007.

[50] M. Farooq, A. Wahid, N. Kobayashi, D. Fujita, and S. M. A. Basra, "Plantdrought stress: effects, mechanisms and management," Agronomy for Sustainable Development, vol. 29, pp. 185-212, 2009.

[51] M. L. Praba, J. E. Cairns, R. C. Babu, and H. R. Lafitte, "Identification of physiological traits underlying cultivar differences in drought tolerance in rice and wheat," Journal of Agronomy and Crop Science, vol. 195, pp. 30-46, 2009.

[52] F. E. Ahmed and A. S. H. Suliman, "Effect of water stress applied at different stages of growth on seed yield and wateruse efficiency of cowpea," Agriculture and Biology Journal of North America, vol. 1, pp. 534-540, 2010.

[53] S. Y. S. Lisar, R. Motafakkerazad, M. M. Hossain, and I. M. M. Rahman, Water Stress in Plants: Causes, Effects and Responses, InTech, West Palm Beach, FL, USA, 2012.

[54] R. M. Chiulele, G. Mwangi, P. Tongoona, J. D. Ehlers, and A. D. Ndeve, "Assessment of cowpea genotypes for variability to drought tolerance," in Proceedings of the 10th African Crop Science Conference, pp. 531-537, Maputo, Mozambique, 2011.

[55] A. Blum, Breeding for Stress Environments, CRC Press, Boca Raton, FL, USA, 1988.

[56] W. J. A. Lalsaga, R. Nan, M. Sawadogo, N. Sawadogo, M. Kiebre, and I. Drabo, "Evaluation de dix (10) génotypes de niébé [Vigna unguiculata (l.) walp.] par rapport à leur tolérance au stress hydrique," International Journal of Innovation and Applied Studies, vol. 14, no. 4, pp. 1005-1014, 2016.
[57] G. Zombre, J. D. Zongo, and E. T. P. Sankara, "Réponse physiologique du niébé au déficit hydrique s'exerçant uniformément au cours du cycle de développement," African Crop Science Journal, vol. 2, pp. 225-310, 1994.

[58] L. Szabados and A. Savoure, "Proline: a multifonctional amino acid," Trends in Plant Science, vol. 15, pp. 89-97, 2009.

[59] G. S. Mauro and C. Pimentel, "Daily balance of leaf sugars and amino acids as indicators of common bean (Phaseolus vulgaris L.) metabolic response and drought intensity," Physiology and Molecular Biology of Plants, vol. 15, no. 1, pp. 23-30, 2009.

[60] R. C. L. Costa, A. K. S. Lobato, C. F. Oliveira Neto, and P. S. P. Maia, "Biochemical and physiological responses in two Vigna Unguiculata (L) Walp. cultivars under water stress," Journal of Agronomy, vol. 7, pp. 98-101, 2008.

[61] R. Santos, M. Carvalho, E. Rosa, V. Carnide, and I. Castro, "Root and agro-morphological traits performance in cowpea under drought stress," Agronomy, vol. 10, no. 10, pp. 1-20, 2020. 